\title{
Toxicological response of the symbiotic sea anemone Aiptasia pallida to butyltin contamination
}

\author{
Annie Mercier ${ }^{1,2,3}$, Émilien Pelletier $^{2}$, Jean-François Hamel ${ }^{3}$ \\ ${ }^{1}$ Département d'océanographie, Université du Québec à Rimouski, Québec, Canada G5L 3A1 \\ ${ }^{2}$ INRS-Océanologie, 310 allée des Ursulines, Rimouski, Québec, Canada G5L 3A.1 \\ ${ }^{3}$ Société d'exploration et de valorisation de l'environnement (SEVE), 90 Notre-Dame Est, Rimouski, Québec, Canada G5L 1Z6
}

\begin{abstract}
This study investigates the fate of tributyltin (TBT), a widespread biocide mainly used in antifouling paints, and of its derivative dibutyltin (DBT) in sea anemones Aiptasia pallida exposed via water or food. Experiments were conducted on both symbiotic and aposymbiotic (lacking zooxanthel-

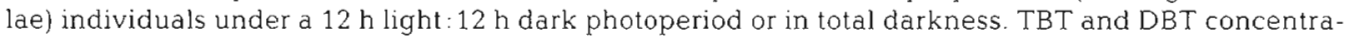
tions in the animal and vegetal compartments were measured over $24 \mathrm{~h}, 30 \mathrm{~h}, 5 \mathrm{~d}, 7 \mathrm{~d}$ and $28 \mathrm{~d}$ periods. Uptake and accumulation from seawater, mainly as DBT due to natural degradation of TBT, was found to be dependent on the presence and illumination of zooxanthellae. DBT concentrations in symbiotic anemones exposed to light were roughly twice those found in individuals maintained in total darkness, and about 10 times greater than in aposymbiotic anemones. A peak accumulation in animal and vegetal tissues occurred after 24 to $48 \mathrm{~h}$ in all symbiotic anemones. A 28 d exposure of symbiotic anemones to a nominal $50 \mathrm{ng} \mathrm{TBT}^{-1}$ resulted in butyltin concentrations under $1 \mathrm{ng} \mathrm{mg}^{-1}$ dry mass. Accumulation most probably occurs through butyltun uptake by zooxanthellae, while their expulsion from the host acts as a depuration process. The presence of zooxanthellae also seems determinant in the regulation and degradation of butyltin ingested with food. Daily ingestion of TBT-contaminated mussel tissue led to sequential debutylation into DBT and monobutyltin (MBT) in symbiotic A. pallida but not in aposymbiotic ones. Over $7 \mathrm{~d}$, aposymbiotic anemones showed close to $100 \%$ retention of ingested TBT, while all butyltin species remained undetected in symbiotic anemones. After $28 \mathrm{~d}$, the retention efficiency was $-68 \%$ in symbiotic anemones in which $-59 \%$ of the butyltin was in the form of DBT
\end{abstract}

KEY WORDS: Accumulation - Aiptasia pallida Degradation - Depuration - Dibutyltin - Sea anemone Tributyltin · Zooxanthellae

\section{INTRODUCTION}

The tight association known as symbiosis that binds many species of marine invertebrates to microscopic algae, generally zooxanthellae, can be observed throughout the world oceans, and involves hosts of numerous phyla ranging from Protozoa to Mollusca. The most impressive array of such associations occurs in benthic communities comprising coral reef ecosystems, where it enables both parties to better survive in their nutrient-poor habitat. A number of studies have investigated the interrelation of symbiotic algae with corals (reviewed by Muscatine 1990), sea anemones

•E-mail: annie_mercier@uqar.uquebec.ca
(Clayton \& Lasker 1984, Cook et al. 1988, Day 1994), hydroids (McAuley \& Cook 1994) and giant clams (Fitt et al. 1993, Yellowlees et al. 1993). However, although the dynamics and sensitivity of symbiotic relations are increasingly well known, to our knowledge, toxicological studies on these associations are still very scarce.

Most existing studies discuss metal tolerance and regulation in symbiotic invertebrates. Regulation and impact of trace metal uptake by corals have been studied in regard to the presence of zooxanthellae (Howard \& Brown 1984, Brown \& Howard 1985, Howard et al. 1986, Harland \& Brown 1989). Accumulation and depuration of arsenic by symbiotic animals, mostly by the giant clam Tridacna, were investigated by Benson \& Summons (1981) and Benson (1990). Similar studies concerning sea anemones have been conducted by 
Brown \& Howard (1985), Harland et al. (1990) and Harland \& Nganro (1990), and refer to the role of zooxanthellae in the regulation of copper, cadmium and zinc Very few organic contaminants have been considered; the bioconcentration factor of chlordane, and its degradation and metabolism by a scleractinian coral and its symbiotic algae, were evaluated by Firman \& Gassman (1995), while bioaccumulation and histopathological effects of oil were assessed in a stony coral (Peters et al. 1981). The need for further studies in those fields is constantly emphasized, especially with the growing concern over the disturbance of coastal regions and coral reefs (Grigg \& Dollar 1991)

Sea anemones are, with their close relatives the corals, among the most abundant representatives of coastal benthic communities, especially in the tropics. The pale sea anemone Aiptasia pallida (Verrill) is a small, common species along the east coast of the United States, most abundant from North Carolina to the Florida Keys (Kaplan 1988). This cnidarian can be found on rocks and other hard substrates in shallow coastal water and it is easy to maintain in the laboratory. Important knowledge already exists on the general physiology of $A$. pallida and its Pacific congener $A$. pulchella, including data on their symbiosis with the zooxanthellae Symbiodinium microadriaticum (Clark \& Jensen 1982, Clayton \& Lasker 1984, Wilkerson \& Muscatine 1984, Muller-Parker 1987, Cook et al. 1988 , Muller-Parker et al. 1990), therefore facilitating the use of this invertebrate in toxicological studies.

Our objective was to determine the response of the zooxanthellae - sea anemone symbiosis toward a contamination of the water or the food by the organometallic compound tributyltin (TBT). This widespread biocide was mainly used as an anti-fouling agent in paints for boat hulls and fishing equipment. Although its use on small craft has been banned in many countries, the occurrence of TBT in the environment is still a case for concern in Europe, Asia and North America (Stewart \& de Mora 1990, Higashiyama et al. 1991, Cocchieri et al. 1993, Espourteille et al. 1993, Uhler et al. 1993, Stewart \& Thompson 1994), but especially in tropical regions like Fiji, where it was recently detected in bivalves and sediment in concentrations up to 3.18 and $38 \mu \mathrm{g} \mathrm{g}^{-1}$ dry mass, respectively (Stewart \& de Mora 1992). Concentrations of TBT and its degradation product dibutylin (DBT) in seawater can reach several $\mu \mathrm{g} \mathrm{l}^{-1}$ in very polluted areas while levels ranging between 10 and $100 \mathrm{ng} \mathrm{l}^{-1}$ are commonly detected (Stewart \& de Mora 1990, Cocchieri et al. 1993). In that regard, shallow coastal populations comprising coral reefs are particularly at risk when it comes to butyltin exposure.

Previous TBT studies that included the concept of trophic transfer were conducted on non-symbiotic mollusks, crustaceans and echinoderms (Evans \& Laughlin
1984, Lee 1985, Bryan et al. 1989, Rice et al. 1989, Mercier et al. 1994, Guolan \& Yong 1995). The present work was designed to compare the accumulation patterns of TBT and DBT via water and food in a symbiotic cnidarian under different conditions. Symbiotic sea anemones under a $12 \mathrm{~h}$ light: $12 \mathrm{~h}$ dark photoperiod or in total darkness and aposymbiotic individuals were studied. We measured butyltin concentrations in the animal and vegetal compartments over time in order to better assess the respective roles played by the symbiotic partners in butyltin degradation, accumulation and depuration. We present here the first experimental data concerning the response of a symbiotic system toward TBT contamination.

\section{MATERIALS AND METHODS}

Maintenance of sea anemones. Sea anemones Aiptasia pallida (Fig. 1) were collected from floating docks, off the coast of Wrightsville Beach, North Carolina, USA ( $\left.34^{\circ} 18^{\prime} \mathrm{N}, 77^{\circ} 81^{\prime} \mathrm{W}\right)$ and shipped to our laboratory by a supplier (Connecticut Valley Biological Supply Inc., Southampton, MA) when needed. Experimental exposures were conducted between January and October 1995. Upon arrival, the sea anemones were immediately distributed in the experimental system which was composed of $1.8 \mathrm{l}$ culture glass bowls, each holding 4 or 5 individuals, continuously supplied with natural filtered $(100 \mu \mathrm{m})$ seawater $\left(20\right.$ to $25^{\circ} \mathrm{C}$, salinity 24 to $28 \%$ o). Two tanks $(2001)$ were used as reservoirs, providing about $10 \mathrm{ml} \mathrm{min}{ }^{-1}$ to each bowl through a multi-channel peristaltic pump. Timercontrolled illumination was provided by cool white fluorescent lamps with an irradiance of 80 to $100 \mu \mathrm{E} \mathrm{cm}^{-2}$ $\mathrm{s}^{-1}$. The sea anemones were left to acclimate to the experimental conditions for 48 to $72 \mathrm{~h}$ prior to contamination. This interval was more than sufficient to allow the anemones to attach themselves to the glass bottom and adopt their fully deployed position. When needed, aposymbiotic individuals (lacking zooxanthellae; Fig. 1b) were obtained by rearing the sea anemones in $10^{-5}$ M 3-(3.4 dichlorophenyl)-1,1 dimethyl urea (DCMU or Diuron) in seawater for 5 to 6 wk (Clayton \& Lasker 1984). DCMU inhibits photosynthesis, therefore depleting the zooxanthellae, without affecting host metabolism or physiological responses (Vandermeulen et al. 1972, Garrigue et al. 1992).

Exposure via seawater. Contamination and sampling procedures: The level of contamination used was similar to the ones previously measured in numerous coastal areas (Stewart \& de Mora 1990, Cocchieri et al. 1993). At the beginning of each experiment $(t=0), 1 \mathrm{ml}$ of TBT (from a $10 \mathrm{ppm}$ solution in ethanol) was added to one of the $200 \mathrm{l} \mathrm{tanks,} \mathrm{in} \mathrm{order} \mathrm{to} \mathrm{achieve}$ 


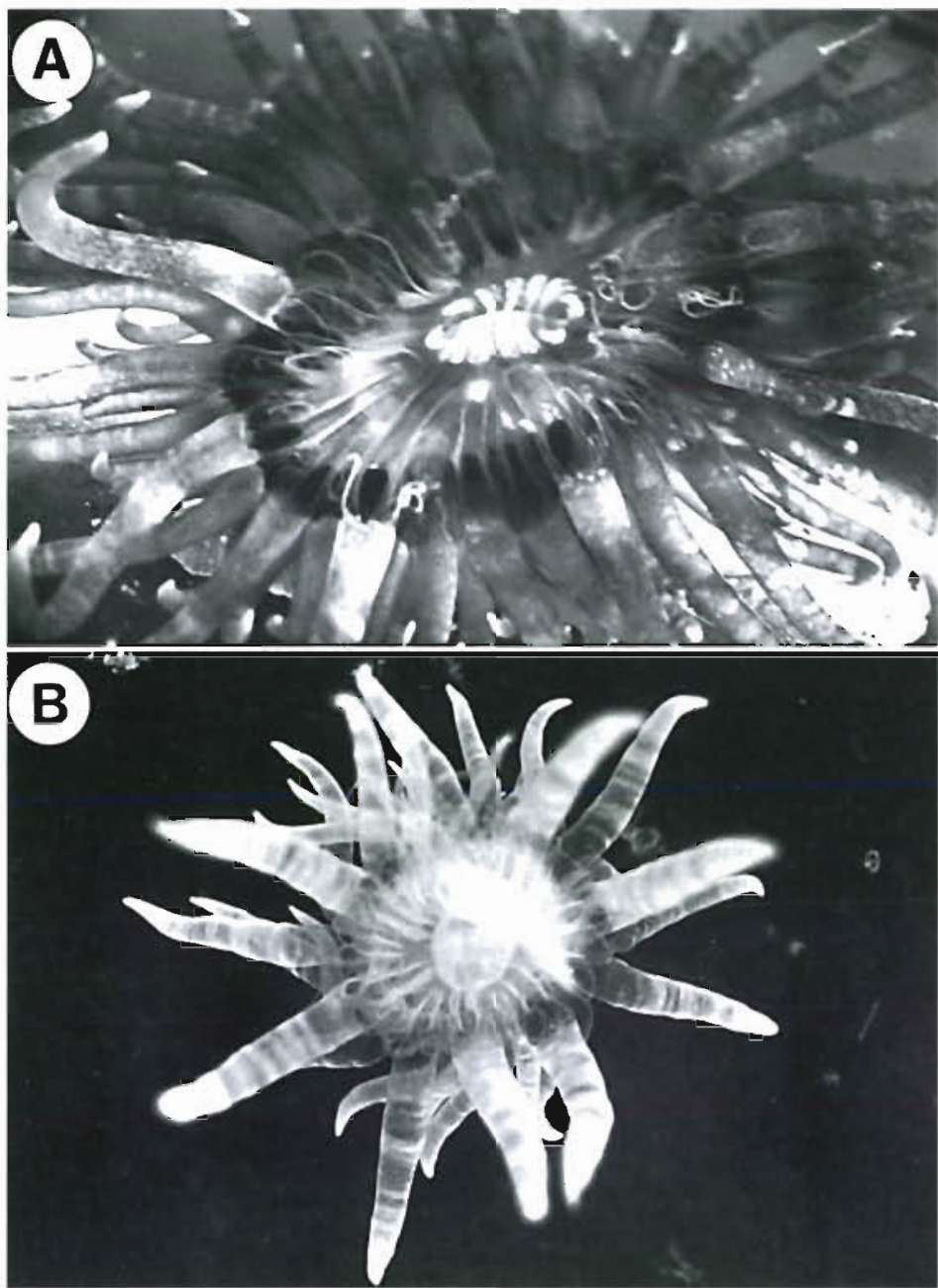

Fig. 1. (A) Symbiotic $(2.6 \times)$ and (B) aposymbiotic sea anemones Aiptasia pallida $(1.3 \times)$. The darker coloration of tentacles and oral disc in $(\mathrm{A})$ indicates the presence of zooxanthellae

a nominal concentration of $50 \mathrm{ng} \mathrm{TBT} \mathrm{l}^{-1}$. The water in the tank was slowly agitated by a submersible pump. Within 10 min, one third of the water in each bow supplied by this tank was removed and replaced with contaminated water, in order to accelerate the establishment of the desired level of contamination around the sea anemones. Following that operation, the bowls were left to be continuously supplied by the peristaltic flow. The other $200 \mathrm{l}$ tank, containing natural seawater and $1 \mathrm{ml}$ of ethanol without TBT, served for the maintenance of control organisms. Both tanks were protected against light to minimize algae growth and photooxidation of TBT

5 d exposure: A 5 d contamination was separately conducted on symbiotic and aposymbiotic sea anemones under a $12 \mathrm{~h}$ light: $12 \mathrm{~h}$ dark photoperiod, and on symbiotic sea anemones in continuous darkness During each of those 3 experiments, 4 to 5 contami- nated sea anemones were sampled after $6 \mathrm{~h}$ and then after every day for $5 \mathrm{~d}$. They were rinsed for a few seconds in uncontaminated seawater and their reduced mass (mass under water) was recorded. They were immediately processed as described below in the chemical analysis procedures. Control sea anemones ( $n=2$ or 3 ) were sampled after $0 \mathrm{~h}, 6 \mathrm{~h}, 3 \mathrm{~d}$ and $5 \mathrm{~d}$, and handled in the same manner to verify the absence of butyltin in the uncontaminated anemones. Also, 2 or 3 samples $(250 \mathrm{ml})$ of the contaminated seawater were collected directly from the supplying tank on Days 1, 2, 4 and 5 to verify the exact butyltin levels.

30 h exposure: In order to achieve a better assessment of the first few hours of butyltin accumulation, a $30 \mathrm{~h}$ experiment was conducted on symbiotic and aposymbiotic sea anemones in light, under $12 \mathrm{~h}$ light : $12 \mathrm{~h}$ dark photoperiod conditions. Contamination and sampling procedures were the same as above. Contaminated sea anemones ( $n=4$ or 5 ) were collected after $0,6,18$ and $30 \mathrm{~h}$, while controls ( $\mathrm{n}=$ 2 or 3 ) were collected at the beginning and at the end of the experiment

$28 \boldsymbol{d}$ exposure: Finally, after we realised that a depuration process was apparently occurring, a longer 28 d experiment was undertaken, using symbiotic sea anemones under the usual photoperiod. The water in the supplying tank was renewed and contaminated once a week to provide contaminated water for the duration of the experiment. Contaminated ( $n=4$ or 5 ) and control $(n=2$ or 3$)$ sea anemones were collected every $7 \mathrm{~d}$.

Exposure via food. Symbiotic and aposymbiotic sea anemones submitted to a $12 \mathrm{~h}$ light: $12 \mathrm{~h}$ dark photoperiod were used and their food consisted of homogenized mussel tissue. During the $72 \mathrm{~h}$ acclimation period, the anemones were fed daily by gently introducing $5 \mathrm{mg}$ of freshly thawed homogenate directly into their buccal cavity with a capillary syringe. All individuals responded very well to this treatment; rejection of food was never observed. We found that ingestion of the food pellet was very rapid, ranging between 30 and $90 \mathrm{~s}$, which is consistent with a previous investigation of the feeding behavior of Aiptasia pallida (Clayton 1986).

$7 \boldsymbol{d}$ exposure: As the study began, half of the sea anemones received contaminated mussel tissue: $5 \mathrm{ng}$ TBT $\mathrm{mg}^{-1}$ wet mass from a stock solution was added to the freshly thawed homogenate, shaken and distributed 10 to 15 min later. Control anemones were given uncon- 
taminated food, containing the same concentration of TBT carrier as the food of contaminated individuals $(\sim 0.25 \mu$ l ethanol per portion). A fraction of the contaminated mussel tissue was later processed for TBT determination. The contaminated sea anemones ( $n=4$ or 5 ) were sampled after $6 \mathrm{~h}$ and then after every day for $7 \mathrm{~d}$. They were rinsed in uncontaminated seawater before having there reduced mass taken and were immediately processed as described in the chemical analysis procedures. Control sea anemones ( $n=2$ or 3 ) were sampled at $0 \mathrm{~h}, 6 \mathrm{~h}, 3 \mathrm{~d}$ and $5 \mathrm{~d}$, and treated in the same manner.

$28 \boldsymbol{d}$ exposure: The same feeding procedure as described above was used over a $4 \mathrm{wk}$ period, under the same experimental conditions. Contaminated and control sea anemones ( $\mathrm{n}=4$ or 5 ) were sampled every $7 \mathrm{~d}$.

24 h exposure to acute concentration: A 24 h experiment was also conducted on symbiotic sea anemones under the usual photoperiod. They were given 2 meals, with a $12 \mathrm{~h}$ interval, of $10 \mathrm{mg}$ mussel homogenate contaminated with $100 \mathrm{ng}$ TBT $\mathrm{mg}^{-1}$ wet mass, using the same technique as described above. Samples $(n=4$ or 5 ) were collected after $0,6,12$ and $24 \mathrm{~h}$.

The different experimental procedures are summarized in Table 1

Chemical analysis. Each fresh anemone was homogenized whole in $1 \mathrm{ml}$ deionized water containing $1 \%$ nitric acid $\left(\mathrm{HNO}_{3}\right)$ with a teflon pestle for 5 to $10 \mathrm{~s}$. The pestle was then rinsed, yielding a $3 \mathrm{ml}$ suspension. Whenever animal and vegetal fractions are mentioned separately, they were obtained by centrifuging the homogenate at $1000 \times g$ for $4 \mathrm{~min}$. The animal supernatant was withdrawn by pipetting, while the zooxanthellal pellet was washed with $2 \mathrm{ml}$ deionized water, agitated and centrifuged once more. The supernatant was pooled with the previous animal fraction and the zooxanthellae were resuspended in $2 \mathrm{ml}$ of deionized water. Clayton \& Lasker (1984) used a similar centrifugation rinsing procedure and determined, after 4 repeated measures, that the contamination of zooxanthellae by host tissue was around $14.2 \%$ and contamination of host tissue around $3.7 \%$. The vegetal and animal samples were thereafter processed separately. Given the absence of vegetal cells in aposymbiotic sea anemones, the centrifugation step was omitted, yielding only animal samples.

All samples were analyzed through the hydride generation technique currently used in our laboratory for biological tissues (Mercier et al. 1994, Saint-Louis et al. 1994). Briefly, tripentyltin was first added to the sample as an internal standard and as a surrogate for recovery determination. Then $2 \mathrm{ml}$ of $1 \%$ tropolone in ethanol $(\mathrm{w} / \mathrm{v})$ was added to the sample which was sealed with a septum cap before introducing $1 \mathrm{ml}$ sodium borohydride $\left(\mathrm{NaBH}_{4} 4 \% \mathrm{w} / \mathrm{v}\right)$ with a syringe. The sample was agitated for $10 \mathrm{~min}$. Finally, $1 \mathrm{ml}$ deionized water and $2 \mathrm{ml}$ hexane were added as well as an external standard (tetrapentyltin). After agitation and centrifugation, the organic fraction was removed and cleaned on a silica gel column $(6 \times 1 \mathrm{~cm}, o . d$.$) , then rinsed with$ hexane. The extract was concentrated under nitrogen to a final volume of $100 \mu$ lof which $1 \mu \mathrm{l}$ was injected in a gas chromatograph coupled to a mass spectrometer (GC-ITD). The remaining animal and vegetal tissues contained in the aqueous fraction were dried to constant mass in an oven at $55^{\circ} \mathrm{C}$, using preweighed aluminium dishes. Routinely, all samples were collected, processed and injected in the same day. A few extracts were stored overnight at $-80^{\circ} \mathrm{C}$ and injected no later than the next morning Numerous preliminary essays proved that freezing the extracts for 12 to $16 \mathrm{~h}$ had no detectable effect on the analytical results.

The acidified seawater samples were run through an activated Envi-18 SepPak column $(3 \mathrm{ml})$ and eluted with $2 \mathrm{ml}$ diethyl ether and $2 \mathrm{ml}$ hexane (Saint-Louis et al. 1994). The subsequent hydride generation procedure was performed as described above. The practical detection limit of this analysis was evaluated at $0.10 \mathrm{ng}$ $\mathrm{mg}^{-1}$ dry tissue mass and $0.02 \mu \mathrm{g} \mathrm{l}^{-1}$ of seawater, for all species of butyltin. Lower levels (about 5 times) could be detected but not accurately quantified. TBT- and DBT-spiked samples yielded recoveries of $87.1 \pm 3.8 \%$ and $100.7 \pm 8.5 \%$ (mean $\pm \mathrm{SD}, \mathrm{n}=8$ ), respectively.

Table 1. Alptasia pallida. Summary of the different experimental procedurns

\begin{tabular}{|c|c|c|c|c|c|c|c|c|c|c|}
\hline \multirow{3}{*}{$\begin{array}{l}\text { Conditions } \\
\text { Rate of TBT exposure } \\
\text { Duration of exposure }\end{array}$} & \multicolumn{6}{|c|}{ Contamination via seawater } & \multicolumn{4}{|c|}{ Contamination via food } \\
\hline & \multicolumn{6}{|c|}{$-500 \mathrm{ng} \mathrm{min}^{-1}$ (flow-through) } & \multicolumn{3}{|c|}{$25 \mathrm{ng} \mathrm{d}^{-1}$} & \multirow{2}{*}{$\begin{array}{c}1000 \mathrm{ng} 12 \mathrm{~h}^{-1} \\
24 \mathrm{~h}\end{array}$} \\
\hline & $5 d$ & $5 d$ & $5 d$ & $30 \mathrm{~h}$ & $30 \mathrm{~h}$ & $28 d$ & $7 d$ & $7 d$ & $28 d$ & \\
\hline Lighting conditions" & L & $\mathrm{D}$ & L & $\mathrm{L}$ & L & L & L & $\mathrm{L}$ & L & $\mathrm{L}$ \\
\hline Type of sea anemone & s & S & A & S & A & S & $\mathrm{S}$ & A & S & $\mathrm{S}$ \\
\hline Tissue analysed & $\begin{array}{l}\text { Anumal } \\
\text { and } \\
\text { vegetal }\end{array}$ & $\begin{array}{l}\text { Animal } \\
\text { and } \\
\text { vegetal }\end{array}$ & $\begin{array}{l}\text { Whole } \\
\text { sea } \\
\text { anemone }\end{array}$ & $\begin{array}{l}\text { Animal } \\
\text { and } \\
\text { vegetal }\end{array}$ & $\begin{array}{l}\text { Whole } \\
\text { sea } \\
\text { anemone }\end{array}$ & $\begin{array}{l}\text { Animal } \\
\text { and } \\
\text { vegetal }\end{array}$ & $\begin{array}{l}\text { Whole } \\
\text { sea } \\
\text { anemone }\end{array}$ & $\begin{array}{l}\text { Whole } \\
\text { sea } \\
\text { anemone }\end{array}$ & $\begin{array}{l}\text { Whole } \\
\text { sea } \\
\text { anemone }\end{array}$ & $\begin{array}{l}\text { Animal } \\
\text { and } \\
\text { vegetal }\end{array}$ \\
\hline
\end{tabular}


RESULTS

\section{Exposure via seawater}

\section{Seawater and controls}

TBT was not the major form of butyltin recovered in the contaminated seawater throughout the experiments (Fig. 2). Instead, DBT was found in much greater amounts, closer to the nominal concentration of $50 \mathrm{ng} \mathrm{l}^{-1}$ This is usual in the environment, where TBT is rapidly degraded within days, most likely through microbial activity (Seligman et al. 1988, Stewart \& de Mora 1990). The phenomenon is probably even more rapid in warm seawater, as was used in our study. Precise dosage in the seawater was difficult, especially for TBT, because the levels remained close to the detection limit. All control sea anemones analyzed were butyltin-free, except 2 symbiotic individuals from 1 treatment that showed the presence of minute amounts of DBT which we could not quantify. It is very unlikely that this apparent contamination came from the seawater used, given the number of controls that were negative $(n \approx 70)$. However, the anemones were collected from floating docks prior to shipment to our laboratory and butyltin contamination in nature is most common near docking facilities, where leakage from hull paints usually has the greatest effect.

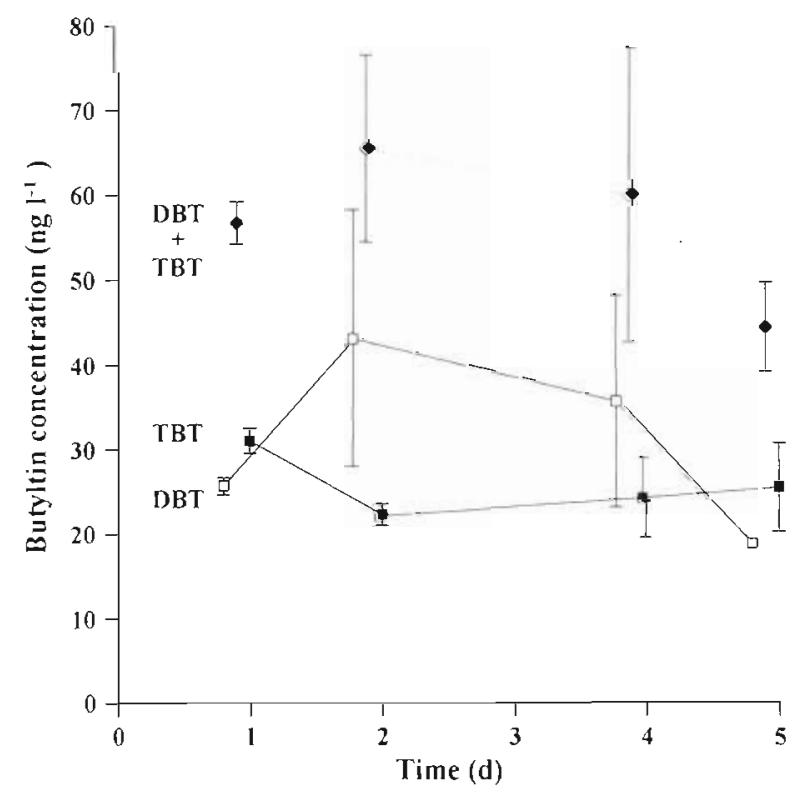

Fig. 2. Actual TBT and DBT concentrations measured in the contaminated seawater over $5 \mathrm{~d}$ (mean $\pm \mathrm{SD}, \mathrm{n}=2$ ). Horizontal dotted line is the practical detection limit
$5 \mathrm{~d}$ exposure

Concurrent with what occurred in the seawater, DBT was the major species recovered in the animal and vegetal tissues of contaminated sea anemones. TBT and monobutyltin (MBT) peaks were sporadically observed in a few symbiotic individuals but concentrations remained below the detection limit, whereas TBT was readily detected in aposymbiotic sea anemones. DBT rather than TBT accumulation will therefore be compared in this experiment and concentrations are given in $\mathrm{ng} \mathrm{mg}^{-1}$ dry mass (mean $\pm \mathrm{SD}$ ).

For all results, statistical difference between the 2 groups was established with a $95 \%$ confidence interval using either the Student's $t$-test, when the data were normally distributed, or the Mann-Whitney rank sum test when equal distribution and normality failed.

A significant increase of DBT concentration in both animal and vegetal fractions (Mann-Whitney rank sum test, $\mathrm{p}<0.05$ ) occurred after $2 \mathrm{~d}$ in symbiotic anemones in light, whereas it occurred within $1 \mathrm{~d}$ in darkness (Fig. 3). This was followed by a drastic drop during the following $24 \mathrm{~h}$ for symbiotic sea anemones in both conditions (Mann-Whitney rank sum test, $p<0.05$ ). DBT concentration in aposymbiotic anemones was roughly constant (Fig. 3).

The peak concentration in the animal fraction was significantly higher (Mann-Whitney rank sum test, $\mathrm{p}=0.03)$ in symbiotic anemones in light $(15.7 \pm 6.8 \mathrm{ng}$ $\mathrm{mg}^{-1}$ dry mass) than in symbiotic anemones maintained in total darkness $\left(5.6 \pm 2.1 \mathrm{ng} \mathrm{mg}^{-1}\right.$ dry mass). This was also true when comparing vegetal fractions of the same anemones (Mann-Whitney rank sum test, $\mathrm{p}=$ 0.01 ) which showed peak DBT concentrations of $14.5 \pm$ $5.3 \mathrm{ng} \mathrm{mg}^{-1}$ dry mass in light and $9.3 \pm 3.2 \mathrm{ng} \mathrm{mg}^{-1}$ dry mass in darkness. The weakest peak accumulation occurred in aposymbiotic anemones in light $2.8 \pm$ $2.7 \mathrm{ng} \mathrm{mg}^{-1}$ dry mass), which significantly differed from the peak concentration found in symbiotic anemones in light (Mann-Whitney rank sum test, $p=0.02$ ) but not with that found in anemones maintained in darkness.

After that peak, the DBT concentration decreased and remained low in all anemones for the duration of the experiment (Fig 3). After 5 d, symbiotic anemones in light still showed the highest level of DBT $15.0 \pm$ $2.1 \mathrm{ng} \mathrm{mg}^{-1}$ dry mass), followed by symbiotic anemones in darkness $\left(2.0 \pm 0.4 \mathrm{ng} \mathrm{mg}^{-1}\right.$ dry mass) and aposymbiotic anemones $\left(1.0 \pm 0.9 \mathrm{ng} \mathrm{\textrm {mg } ^ { - 1 }}\right.$ dry mass $)$. Although the final concentration in both animal and vegetal fractions significantly differed between symbiotic anemones in light and the 2 other treatments (Mann-Whitney rank sum test, $\mathrm{p}<0.05$ ), the difference was not significant between aposymbiotic anemones 


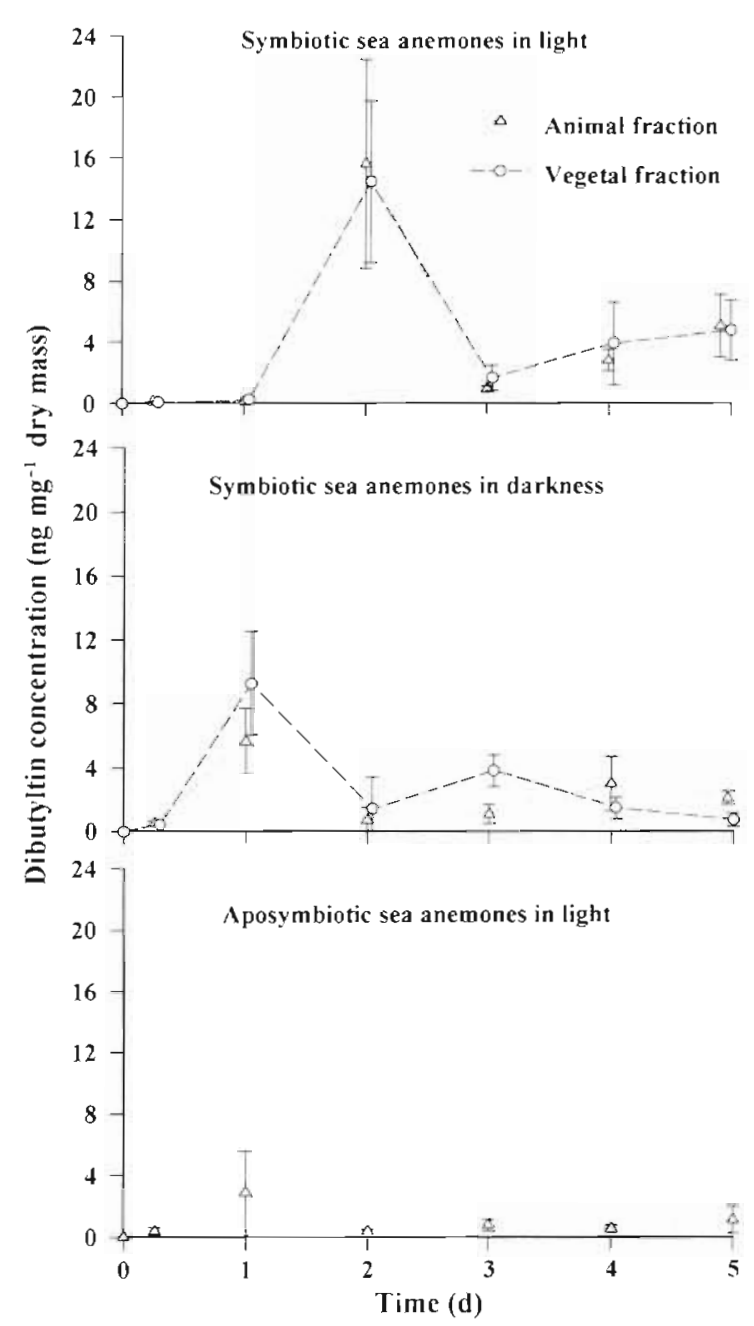

Fig. 3. Aiptasia pallida. DBT concentration in sea anemones over a 5 d exposure to a nominal TBT concentration of $50 \mathrm{ng} \mathrm{l}^{-1}$ Results are shown for animal and vegetal tissues of symbiotic sea anemones in light and in darkness as well as for whole aposymbiotic sea anemones in light (mean $\pm \mathrm{SD}, \mathrm{n}=4$ or 5)

and symbiotic anemones in darkness (Mann-Whitney rank sum test, $p>0.05$ )

Comparison between the concentrations in animal and vegetal fractions of symbiotic sea anemones in light revealed no clear difference (Fig 3). Symbiotic anemones in darkness did not show a significant departure at the $24 \mathrm{~h}$ peak ( $t$-test, $\mathrm{p}>0.05$ ), but they had a significantly higher DBT concentration in the vegetal fraction after $3 \mathrm{~d}$ ( $t$-test, $\mathrm{p}=0.004)$ and in the animal fraction after $5 \mathrm{~d}$ ( $t$-test, $\mathrm{p}=0.002$ ). Total concentrations in anemones exposed to light, combining animal and vegetal fractions and all species of butyltin, was about twice that found in symbiotic anemones kept in darkness and up to 10 times greater than in aposymbiotic anemones.

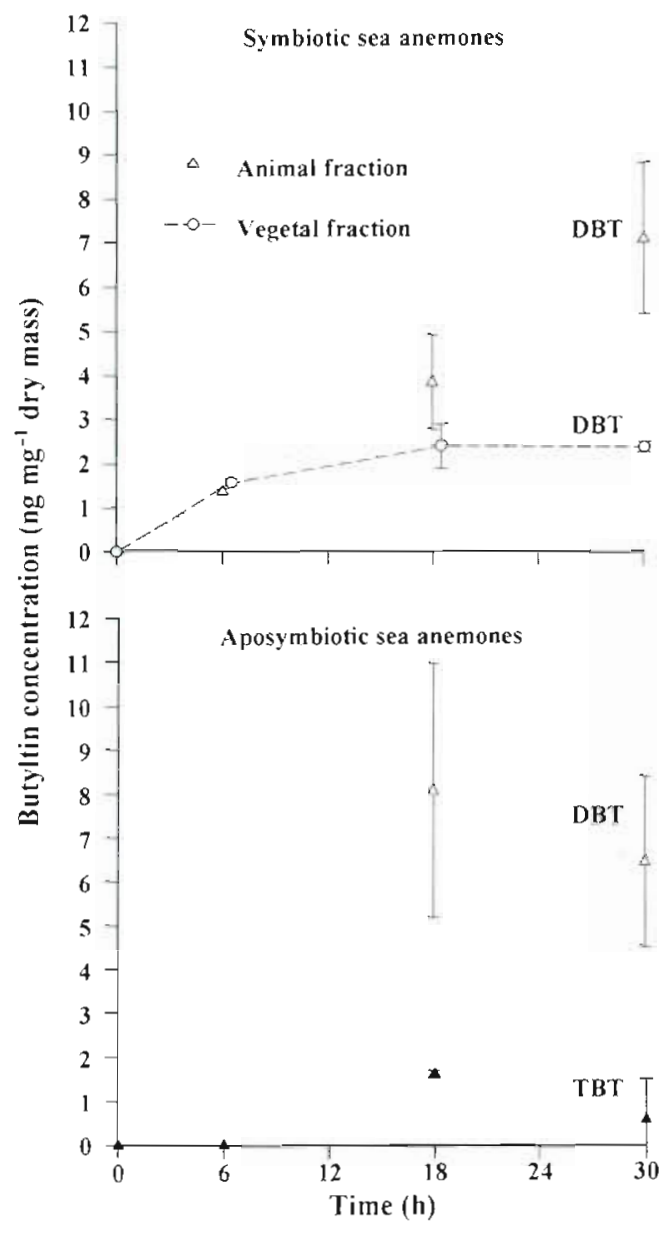

Fig. 4. Aiptasia pallida. Butyltin concentration in anımal and vegetal fractions of symbiotic sea anemones and aposymbiotic sea anemones in light over a $30 \mathrm{~h}$ exposure to a nomunal

TBT concentration of $50 \mathrm{ng} \mathrm{l}^{-1}$ (mean $\pm \mathrm{SD}, n=4$ or 5 )

\section{$30 \mathrm{~h}$ exposure}

This short-term experiment suggested that a maximum DBT accumulation occurred in aposymbiotic anemones around $18 \mathrm{~h}$, when DBT concentration reached $8.1 \pm 2.9 \mathrm{ng} \mathrm{mg}^{-1}$ dry mass (Fig. 4). After $30 \mathrm{~h}$, DBT accumulation was not significantly different ( $t$-test, $p>0.05)$ in animal fractions between symbiotic anemones (7.0 $\pm 1.7 \mathrm{ng} \mathrm{mg}^{-1}$ dry mass) and aposymbiotic ones $\left(6.5 \pm 1.9 \mathrm{ng} \mathrm{mg}^{-1}\right.$ dry mass) This $30 \mathrm{~h}$ exposure also confirmed that TBT appeared only in aposymbiotic sea anemones, although remaining below $2 \mathrm{ng} \mathrm{mg}^{-1}$ dry mass (Fig 4). Symbiotic anemones in light showed a significantly lower accumulation of DBT in their zooxanthellae than in animal tissues ( $t$-test, $p=0.01)$, with $2.3 \pm 0.1$ and $7.0 \pm 1.7 \mathrm{ng} \mathrm{mg}^{-1}$ dry mass, respectively, after $30 \mathrm{~h}$. 
Fig. 5. Aiptasia pallida. DBT concentration in animal and vegetal fractions of symbiotic sea anemones in light over a 28 d exposure to a nominal TBT concentration of $50 \mathrm{ng} \mathrm{l}^{-1}($ mean $\pm \mathrm{SD}, \mathrm{n}=4$ or 5 )

\section{$28 \mathrm{~d}$ exposure}

Over a 28 d contamination, symbiotic anemones in light showed low levels of DBT accumulation, both in animal and vegetal fractions (Fig. 5). The zooxanthellae fraction showed an undetectable concentration after $21 \mathrm{~d}$, while animal tissues were left with below $1 \mathrm{ng}$ DBT $\mathrm{mg}^{-1}$ dry mass after $28 \mathrm{~d}$.

\section{Exposure via food}

Mussel homogenates and controls

After analyzing the contaminated mussel homogenates that were served as food, we found that the actual TBT concentration in them was $4.9 \pm 1.4 \mathrm{ng} \mathrm{mg}^{-1}$ wet mass (mean $\pm \mathrm{SD}, \mathrm{n}=7$ ). This is fairly close to the nominal concentration of $5 \mathrm{ng} \mathrm{mg}^{-1}$ wet mass that was intended. No other butyltin species was recovered from the mussel homogenates. The whole $5 \mathrm{mg}$ portion of homogenate was easily ingested by all sea anemones in a few seconds and Clayton (1986) has demonstrated that digestion time is in the order of 5 to $8 \mathrm{~min}$. The control sea anemones sampled during all experiments were butyltin-free.

\section{$7 \mathrm{~d}$ and $28 \mathrm{~d}$ exposures}

The daily contamination of aposymbiotic anemones led to a TBT concentration of $1.4 \pm 0.1 \mathrm{ng} \mathrm{mg}^{-1}$ dry mass (mean \pm SD) after $7 \mathrm{~d}$ (Fig. 6). Accumulation remained below the detection limit from Days 1 to 3 and then rose to a steady concentration which was maintained until the end of the experiment (Fig. 6). No other butyltins where detectable in the tissues. During the same $7 \mathrm{~d}$ delay, symbiotic anemones did not show any detectable level of butyltin. As the exposure of symbiotic anemones was prolonged over a 28 d period, butyltins appeared only after $21 \mathrm{~d}$ of daily contamination (Fig. 7). TBT and DBT were detected at roughly the same concentration after that time, $1.4 \pm 1.3$ and $1.5 \pm 0.2 \mathrm{ng} \mathrm{mg}^{-1}$ dry mass respectively. Only DBT concentration increased significantly during the following week of contamination ( $t$-test, $p=0.02$ ), reach-

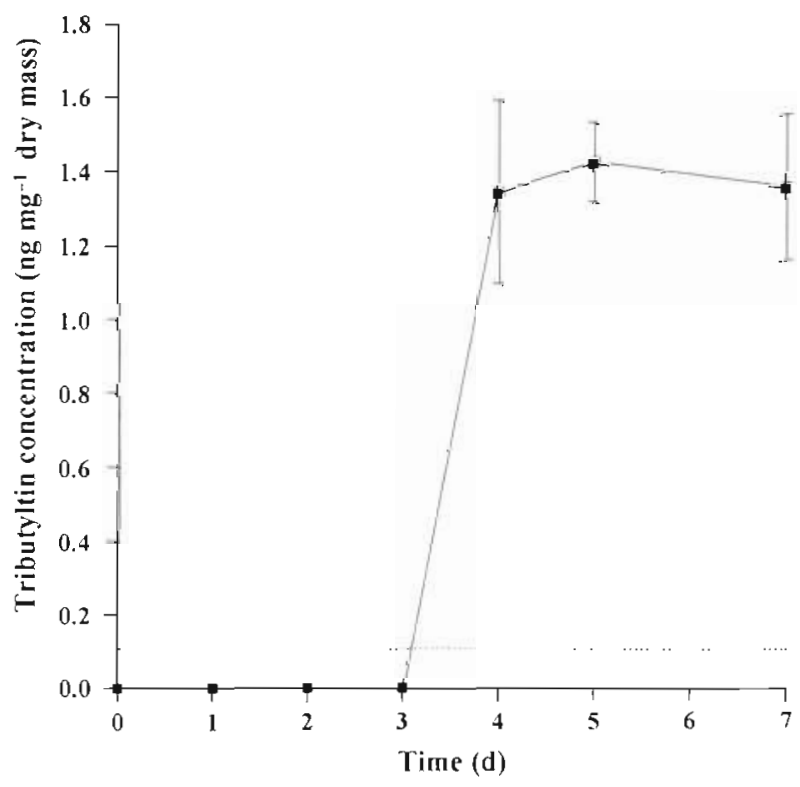

Fig. 6. Aiptasia pallida. Accumulation of tributyltin in aposymbiotic sea anemones over $7 \mathrm{~d}$ of contamination via food (5 $\mathrm{ng} \mathrm{mg}^{-1}$ wet mussel homogenate mass) (mean $\pm \mathrm{SD}, \mathrm{n}=4$ or 5). Horizontal dotted line is the practical detection limit 


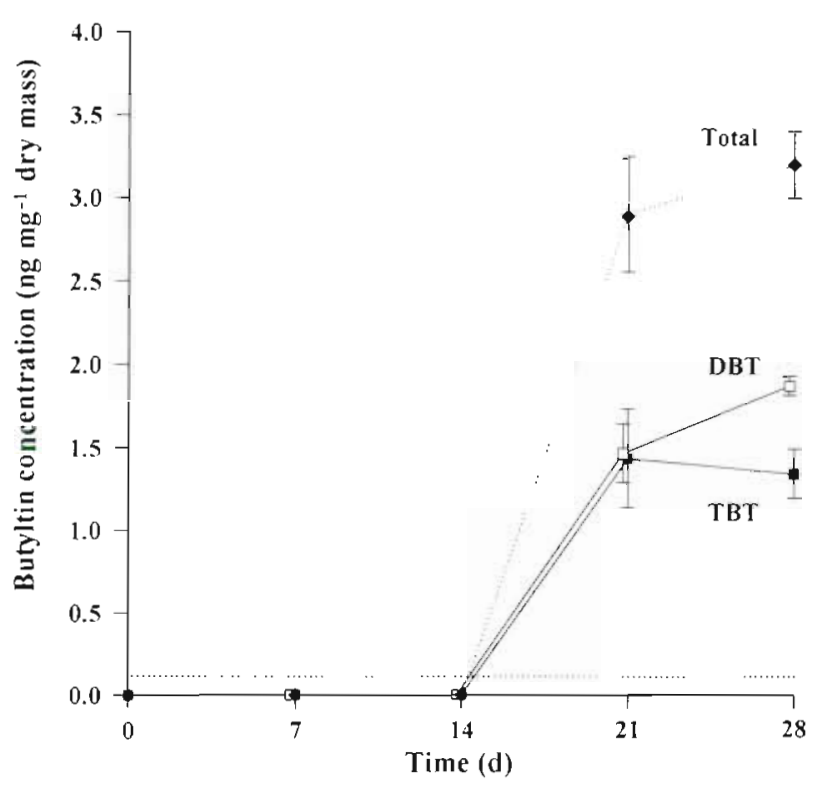

Fig. 7. Aiptasia pallida. Accumulation of butyltin in whole symbiotic sea anemones over $28 \mathrm{~d}$ of contammation via food (5 $\mathrm{ng} \mathrm{mg}^{-1}$ wet mussel homogenate mass) (mean $\pm \mathrm{SD}, \mathrm{n}=4$ or 5). Horizontal dotted line is the practical detection limit

ing $1.9 \pm 0.1 \mathrm{ng} \mathrm{mg}^{-1}$ dry mass. Thus, after $28 \mathrm{~d}$ DBT accumulation was significantly higher ( $t$-test, $p=0.004$ ) than that of TBT which remained relatively stable at $1.3 \pm 0.1 \mathrm{ng} \mathrm{\textrm {mg } ^ { - 1 }}$ dry mass (Fig. 7).

Comparison of the accumulation in aposymbiotic anemones after $7 \mathrm{~d}$ (Fig. 6) with that found in symbiotic anemones after $28 \mathrm{~d}$ (Fig. 7) revealed that TBT levels in the 2 groups were not significantly different ( $t$-test, $\mathrm{p}>0.05$ ), while DBT in symbiotic individuals attained a higher concentration than TBT in aposymbiotic individuals ( $t$-test, $p=0.001)$. Overall butyltin concentration in symbiotic anemones, after combining TBT and DBT, was $3.2 \pm 0.2 \mathrm{ng} \mathrm{mg}^{-1}$ dry mass at the end of the 28 d period, which was roughly twice the concentration found in aposymbiotic anemones after 1 wk.

\section{$24 \mathrm{~h}$ exposure to acute concentration}

The $24 \mathrm{~h}$ experiment involving 4 times the amount of daily food offered to the anemones with 20 times the TBT concentration previously used provided a finer portrait of butyltin accumulation, especially since the butyltin concentrations were separately measured in the animal and vegetal fractions of symbiotic sea anemones during that experiment (Fig. 8). After the first 6 h, DBT was accumulated in clearly higher concentrations than
TBT, in both the animal and vegetal fractions ( $t$-test, $\mathrm{p}<$ $0.05)$. The next $18 \mathrm{~h}$ revedled that butyltin concentrations remained relatively steady and did not show any significant increase ( $t$-test, $p>0.05$; Fig. 8). After $24 \mathrm{~h}$, DBT and TBT concentrations in animal tissues were not significantly different, at $2.0 \pm 0.6$ and $1.6 \pm 0.5 \mathrm{ng} \mathrm{mg}^{-1}$ dry mass respectively. At that same time in the zooxanthellae, DBT levels were significantly higher than TBT levels ( $t$-test, $\mathrm{p}=0.02$ ), with $2.1 \pm 0.2 \mathrm{ng} \mathrm{mg}^{-1}$ dry mass and $1.5 \pm 0.2 \mathrm{ng} \mathrm{mg}^{-1}$ dry mass respectively (Fig. 8).

The total DBT accumulation in this short-term, acute concentration experiment, combining animal and vegetal fractions, was $4.0 \pm 0.6 \mathrm{ng} \mathrm{mg}^{-1}$ dry mass, while it was $3.4 \pm 0.5 \mathrm{ng} \mathrm{mg}^{-1}$ dry mass for TBT. Comparing these overall concentrations to the ones showed by symbiotic anemones after $28 \mathrm{~d}$ of exposure to a lesser contamination revealed that DBT concentrations at the end of the 2 experiments were significantly different (Mann-Whitney rank sum test, $p=0.02$ ). TBT levels were close to 3 times higher after the $28 \mathrm{~d}$ exposure.

\section{Retention efficiency}

Table 2 compares the total amount of TBT given to the sea anemones in each treatment with the amount of butyltin recovered at the end of the exposure.

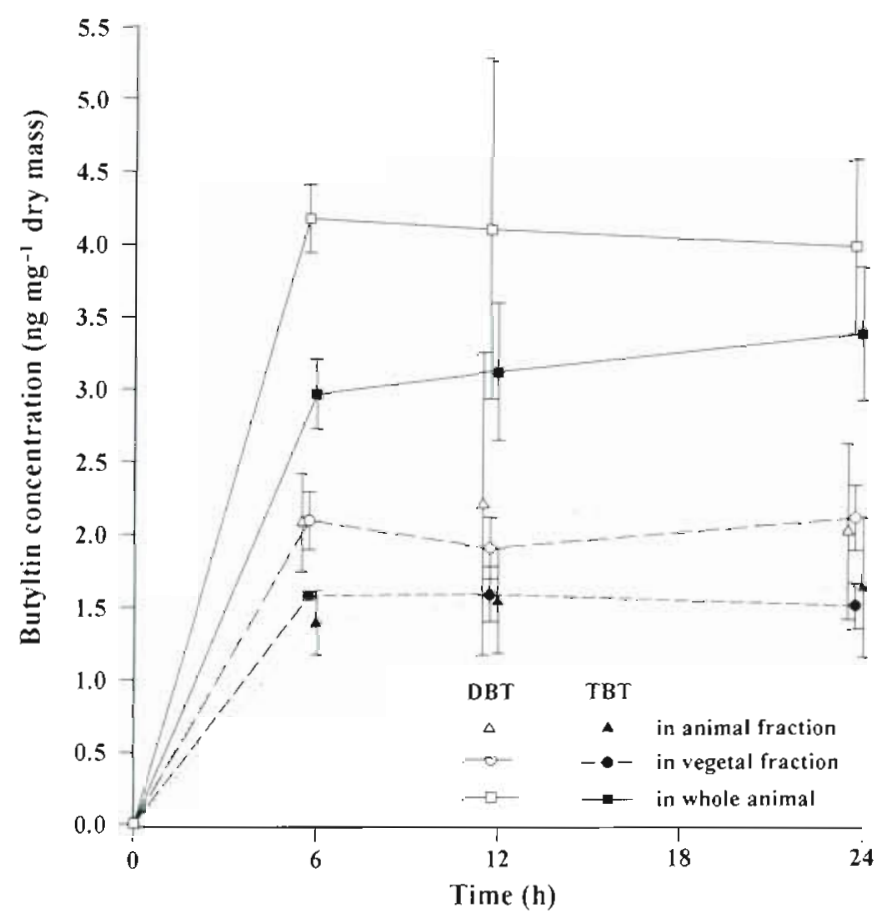

Fig. 8. Aiptasia pallida. Accumulation of butyltin in animal and vegetal fractions of symbiotic sea anemones over 24 h of contamination via food (100 $\mathrm{ng} \mathrm{mg}^{-1}$ wet mussel homogenate mass) (mean $\pm \mathrm{SD}, \mathrm{n}=4$ or 5 ) 
Table 2. Ajptasia pallida. Comparison between the parameters and corresponding burdens obtained during different experimental exposures to contaminated food (mean $\pm \mathrm{SD}, \mathrm{n}=4$ or 5). nd: 'non detected' (below the detection limit)

\begin{tabular}{|c|c|c|c|c|}
\hline & \multicolumn{4}{|c|}{ Type of sea anemone } \\
\hline & Symbiotic & Aposymbiotic & Symbiotic & Symbiotic \\
\hline Daily TBT dosage (ng) & 25 & 25 & 25 & 2000 \\
\hline Length of exposure (d) & 7 & 7 & 28 & 1 \\
\hline Total TBT ingested (ng) & 175 & 175 & 700 & 2000 \\
\hline $\begin{array}{l}\text { TBT in whole animal at the end } \\
\text { (ng mg dry mass) }\end{array}$ & nd & $1.4 \pm 0.1$ & $1.3 \pm 0.2$ & $3.4 \pm 0.5$ \\
\hline $\begin{array}{l}\text { DBT in whole animal at the end } \\
\text { (ng } \mathrm{mg}^{-1} \text { dry mass) }\end{array}$ & nd & nd & $1.9 \pm 0.1$ & $4.0 \pm 0.6$ \\
\hline Total butyltin burden at the end (ng) & nd & $172 \pm 9$ & $474 \pm 15$ & $1578 \pm 224$ \\
\hline Total burden / amount of TBT ingested (\%) & 0 & $98 \pm 5$ & $68 \pm 2$ & $79 \pm 11$ \\
\hline
\end{tabular}

Aposymbiotic anemones roughly accumulated all the TBT present in their food over 1 wk, while symbiotic anemones accumulated butyltin levels under our detection limit over that same period. Symbiotic anemones fed contaminated mussel tissue for a longer period (e.g. 28 d) took up around $68 \%$ of the TBT they were fed and accumulated roughly $59 \%$ of it in the form of DBT (Table 2). Finally, symbiotic anemones fed highly contaminated food (100 $\mathrm{ng} \mathrm{mg}^{-1}$ wet mass) over $1 \mathrm{~d}$ accumulated nearly $80 \%$ of the TBT they were given, with about $55 \%$ of it in the form of DBT. Although a monobutyltin (MBT) peak did appear in roughly $25 \%$ of the symbiotic individuals over the course of the $24 \mathrm{~h}$ and $28 \mathrm{~d}$ experiments, we were not able to quantify it most of the time.

\section{DISCUSSION}

Exposure of symbiotic sea anemones to TBT via food and water resulted in butyltin accumulations less than 1 and $3.5 \mathrm{ng} \mathrm{mg}^{-1}$ dry mass, respectively, over a $28 \mathrm{~d}$ period (Figs. $5 \& 7$ ). The peak and overall amounts of butyltin found in the sea anemones exposed to contaminated water seemed related to the presence and illumination of zooxanthellae (Fig. 3). During exposure via food, symbiotic individuals were able to delay butyltin accumulation in animal and vegetal tissues for $21 \mathrm{~d}$ (Fig. 7) and showed sequential debutylation abilities (Figs. $7 \& 8$ ). In contrast, aposymbiotic anemones accumulated TBT without degrading it within $4 \mathrm{~d}$ (Fig. 6). These observations stress the dual uptake and depuration role of zooxanthellae which enhance the ability of sea anemones to regulate butyltin accumulation. Degradation of TBT by zooxanthellae followed by their gradual expulsion from the host are probably part of the main processes of butyltin regulation during both types of contamination, although storage and/or excretion of tin compounds by the anemone may also be involved.
The principal aim of this work was to gather realistic data on the response of a symbiotic system toward a TBT contamination. We therefore used a level of contamination similar to the ones previously measured in numerous coastal areas (Stewart \& de Mora 1990, Cocchieri et al. 1993). As a consequence, the DBT levels found in Aiptasia pallida fall within the range of butyltin concentrations measured in biota from mildly to highly contaminated areas around the world (Espourteille et al. 1993, Uhler et al. 1993, Stewart \& Thompson 1994).

\section{Influence of zooxanthellae on butyltin uptake from seawater}

Studies of butyltin bioaccumulation from seawater in marine invertebrates have largely focused on bivalves. The pattern of butyltin accumulation observed in sea anemones is not comparable to the one generally associated with mussels. Guolan \& Yong (1995), for instance, measured a constantly increasing bioaccumulation in gill and viscera of Mytilus edulis during exposure to $0.5 \mu \mathrm{g} \mathrm{TBTCl} \mathrm{l}^{-1}$ in a continuous system over $60 \mathrm{~d}$. Concentrations in the same tissues increased to reach a steady state after $25 \mathrm{~d}$ of exposure to lower concentrations. In contrast, symbiotic sea anemones accumulate the greatest concentrations during the first few hours or days, while their depuration potential over time appears to surpass that of mussels, at least over a $28 \mathrm{~d}$ period (Figs. $3 \&$ 5). Although physiological differences between bivalves and sea anemones are obviously involved, this pattern is certainly related to the symbiotic nature of Aiptasia pallida.

Before any further discussion, it is appropriate to look into the purpose and basic dynamics of anemone-algae symbiosis. The incorporation of autotrophic vegetal cells by a heterotrophic animal in- 
creases its trophic flexibility and improves the ability of both parties to survive in nutrient-poor environments (Shick 1991). The symbiotic algae, in this case zooxanthellae, occur singly in membrane-bounded vacuoles localized within the endodermal cells of the host, mostly in the tentacles and oral disc. This intracellular location, designed to maximize direct exposure to sunlight, also allows the host to control the release of algal photosynthates, both physiologically and through behavioral adjustment of the illumination provided to zooxantheliae. The anemone can regulate the growth and density of the algal population as well (Shick 1991).

The initial butyltin accumulation in Aiptasia pallida can be correlated with zooxanthellae-host interactions regarding dissolved environmental substances. The major source of butyltin in our experimental design was DBT (Fig. 2), which mimics field conditions where the concentration of DBT in organisms is usually higher than that of TBT (Seligman et al. 1988, Stewart \& de Mora 1990), Our results clearly show that symbiotic anemones accumulate about 10 times as much DBT in their whole tissues as aposymbiotic anemones over $5 \mathrm{~d}$. Further, the presence of light, which influences zooxanthellae photosynthesis, also has an impact: symbiotic anemones maintained in light show DBT concentrations that are roughly twice those found in symbiotic anemones maintained in total darkness (Fig. 3). DBT accumulation therefore appears to depend on the presence, and, although not entirely, on the illumination of symbiotic zooxanthellae

These results concur with previous studies of the interaction between zooxanthellae and sea anemones or corals which have shown that zooxanthellae play a major role in the nutrition, and hence survival, of their cnidarian hosts (Muscatine 1974. Trench 1981, Hinde 1988. Muscatine 1990). They translocate reduced organic carbon and nitrogen to the host, probably increase the recycling of nutrients such as phosphorus and nitrogen in the system and accelerate the rate of calcium deposition by coral polyps (Muscatine 1974, Clark \& Jensen 1982, Steen \& Muscatine 1984). It would be fair to suppose that, because of their partially organic nature, butyltins may be taken up by zooxanthellae as readily available carbon. Heterotrophic uptake of organic material by zooxanthellae in symbiosis with the Pacific congener of Aiptasia pallida, A. pulchella, has already been proposed (Steen 1986). Butyltin always seems to be efficiently translocated to the host's tissues, as demonstrated by the relatively equal distribution of DBT in animal and vegetal fractions of symbiotic sea anemones (Fig. 3). However, uptake alone would lead to constant accumulation of DBT, whereas we observed a significant loss of DBT from both animal and vegetal compartments of the sea anemones. A complementary process is therefore involved.

Since butyltin molecules have a metallic moiety, we should also look into metal regulation by symbiotic invertebrates to elucidate the DBT accumulation pattern in Aiptasia pallida. Harland et al. (1990) found that zooxanthellae in sea anemone Anemonia viridis accumulated twice the amount of cadmium and zinc as that accumulated by the body as a whole. Moreover, they showed greater levels of zinc and cadmium accumulation in this symbiotic species than in the nonsymbiotic Actinia equina they tested. Further, expulsion of the contaminated zooxanthellae by the host was often proposed as a means of depuration in corals (Howard et al. 1986. Harland \& Brown 1989) and sea anemones (Harland \& Nganro 1990). However, the metal concentrations studied ranged from 2 to $1000 \mu \mathrm{g}$ $1^{-1}$, which is 4 to 2000 times the nominal TBT concentration used, and expulsion of algae was not noticed after exposure to the lowest concentrations.

Our results can only be explained by pooling available knowledge of metal and nutrient regulation in symbiotic anemones. Carbon and nutrients are readily made available to sea anemones, even at low concentrations, through zooxanthellae uptake from seawater. Conversely, biologically significant metals are usually not accumulated by symbiotic animals, except when high concentrations are reached in their immediate environment, at which time the expulsion of algae occurs as a depuration process (Brown \& Howard 1985, Harland \& Nganro 1990, Harland et al 1990 ). In the present work, symbiotic sea anemones seemed to combine both mechanisms: first they accumulated DBT through an uptake process very similar to that of carbon and nutrients via the zooxanthellae, then DBT concentrations decreased, simulating metal regulation

Despite the evident role of zooxanthellae in the uptake of butyltin from seawater, small amounts of DBT appeared in aposymbiotic anemones (Fig. 3) However, they showed a more linear pattern without any marked accumulation or depuration process. This could result from numerous factors. Butyltins are known to adsorb easily on organic surfaces (Powers \& Beavis 1991). Sea anemones are soft-bodied animals and continually pump ambient seawater to deploy their column and tentacles. Their inner and outer membranes were therefore constantly in contact with dissolved DBT and part of their contamination was evidently passive. Also, even though the aposymbiotic individuals looked white and translucent (Fig. 1b), a very reduced and visually undetectable algal population could have remained in their tissues, favouring a minute uptake of DBT 


\section{Toxicological response of sea anemones}

The response of sea anemones was quite rapid. An apparent depuration occurred within a day (Fig. 3), following the peak of DBT accumulation between 24 and $48 \mathrm{~h}$. In order to lower the DBT concentration so efficiently in both animal and vegetal tissues, changes in the physiological and/or behavioral relations between symbiotic partners must have occurred. Could there be a feedback signal from the host that rejects uptake and translocation of butyltin-based products? Special factors in host tissues have been demonstrated to inhibit specific uptake by zooxanthellae, such as that of alanine (Blanquet et al. 1988). Although more DBT was found in the zooxanthellae than in the anemone tissues during the first few hours in anemones exposed to light, this difference phased out after $30 \mathrm{~h}$, suggesting that uptake from zooxanthellae was effectively lowered. Symbiotic anemones in darkness showed less synchronized patterns between animal and vegetal fractions, perhaps indicating that light is an important factor in translocation processes.

Were the contaminated zooxanthellae extruded by the disturbed anemones, as proposed for metal regulation? Gradual whitening of the symbiotic animals was in fact observed during the experiments, as well as visible contraction of the tentacles. A plausible explanation, therefore, emerges from the knowledge that the degree of photosynthetic activity of zooxanthellae can be regulated by the host through contraction of the tentacles (Glider et al. 1980). The peak accumulation could result from the first few hours of contamination, during which the anemones are fully extended and uptake by zooxanthellae is most efficient, especially in light-exposed anemones. Further on, uptake of DBT could be reduced as the anemones adopt a more contracted position, much less favourable to photosynthesis. The fact that aposymbiotic anemones were not observed to retract, as were the symbiotic anemones exposed to light, supports the hypothesis that this behaviour was meant to reduce photosynthesis of zooxanthellae, rather than as an adverse effect of contamination. Control over cell division, and hence growth of the zooxanthellae population, is also known to occur (Shick 1991). Reverse translocation of butyltin from host tissues to zooxanthellae could have been concurrent with expulsion of zooxanthellae, since DBT levels dropped and never came up again, even after 28 d of continuous contamination. However, other means of excretion and the possibility that an undetected form of tin was stored in the algae or animal tissues cannot be ruled out. Degradation intermediates such as hydroxybutyltins, which remain undetected by GC-ITD, have previously been proposed to occur in TBT contaminated starfish (Mercier et al. 1994) and algae (Lee et al. 1989).

\section{Accumulation and degradation of TBT following exposure via food}

The presence of TBT in aposymbionts and its absence in symbiotic anemones during the $24 \mathrm{~h}$ acute contamination via water (Fig. 4) implies that the zooxanthellae also play a role in TBT debutylation. Contamination via food was helpful in determining the degradation and real depuration abilities of zooxanthellae because the dose was constant and virtually $100 \%$ TBT. This kind of exposure adequately completed our assessment since absorption from the diet is considered an important factor in butyltin accumulation for many species. For instance, up to $50 \%$ of the body burden of TBT in dogwhelks Nucella lapillus was determined to come from food after a 49 d exposure to a contaminated environment (Bryan et al. 1989). Is food important to symbiotic animals, even though they can usually rely on photosynthetic algae to provide a major part of their nutritional needs when food is scarce? Symbiotic sea anemones, like other symbiotic cnidarians, still need to feed. In fact, cessation of feeding by Aiptasia pallida was correlated with nutrient deficiency in the zooxanthellae (Cook et al. 1988, 1992). Periodical meals are therefore a necessity for the symbiosis to remain healthy. In that regard, TBT contamination of symbiotic sea anemones via food is as much a threat as exposure through the water medium and both are likely to occur in the field, especially since sea anemones are efficient opportunistic predators.

It was found that aposymbiotic sea anemones could not metabolize ingested TBT into DBT and MBT, at least not over a $7 \mathrm{~d}$ period (Fig. 6). Symbiotic sea anemones were, in turn, very efficient in degrading TBT, even at high concentrations over a short period (Figs. $7 \& 8$ ). Sequential debutylation of TBT has been demonstrated in other marine invertebrates. Blue crabs Callinectes sapidus fed grass shrimp abdomens contaminated with about $2 \mu \mathrm{g} \mathrm{TBT} \mathrm{g}^{-1}$ wet mass were found to debutylate the contaminant into DBT and MBT over a 16 d exposure (Rice et al. 1989). Metabolism of TBT ingested with food was also observed in starfish (Mercier et al. 1994): the daily ingestion of a

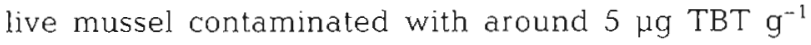
wet mass led to sequential debutylation within 2 wks. Metabolism of TBT by marine animals is usually correlated with the presence of the cytochrome P-450 dependent mixed-function oxidase (MFO) system (Fish et al. 1976, Lee 1991). Although its presence and high activity have been demonstrated in crustaceans (Lee 1991) and echinoderms (Den Besten et al. 1990), its occurrence is still speculative in freshwater cnidarians (Khan et al. 1972), while only low activity was recently determined in a scleractinian coral (Gassman \& Kennedy 1992). Sea anemones could possess a MFO 
system with a low activity similar to that found in this coral or in bivalves which are known for their poor ability to degrade TBT and other toxicants (Lee 1991). On the other hand, numerous species of algae are able to rapidly degrade TBT (Maguire et al. 1984, Lee et al. 1989, Saint-Louis et al. 1994, Guolan \& Yong 1995). This emphasizes the potential role of zooxanthellae in TBT metabolism by symbiotic sea anemones, possibly through a heterotrophic uptake similar to the one observed in symbiotic algae of Aiptasia pulchella (Steen 1986)

Regulation of ingested TBT in Aiptasia pallida is further characterized when comparing the total butyltin burdens at the end of each experiment (Table 2). While aposymbiotic individuals appear to accumulate a TBT burden comparable to the amount of TBT ingested, symbiotic individuals, aside from debutylating TBT, do not accumulate butyltins as effectively. Only between 68 and $79 \%$ of the butyltin given was recovered in those individuals (Table 2). Part of the remaining fraction is liable to be in the form of MBT, which was sporadically observed. Depuration could have resulted from the expulsion of contaminated zooxanthellae, as previously suspected during contamination via seawater. If occurring, this phenomenon is more likely to have had an impact over the 28 d contamination rather than over $24 \mathrm{~h}$. Comparison of the total burdens at the end of those 2 experiments seems to agree: about $68 \%$ of the butyltin burden was recovered after $28 \mathrm{~d}$ compared to $79 \%$ over 24 h (Table 2). Aside from zooxanthellae release, tin could also have been stored in an undetectable form. Excretion via the faecal pellets is apparently not a major factor since aposymbiotic anemones retained roughly all the TBT they ingested.

\section{Conclusion and perspectives}

This work brings first evidence for TBT degradation by zooxanthellae and regulation of butyltin in a symbiotic organism exposed via water and food. Both types of contamination are suspected to be detrimental to the symbiosis itself, as parting of the zooxanthellae from the host seems to be the key factor in the depuration process. Long-term exposure to TBT may well result in an irreversible destruction of the symbiosis and threaten the survival of both partners in severely contaminated areas. Histological studies will certainly contribute to a better understanding of the overall impact of TBT contamination on symbiotic sea anemones (Mercier et al unpubl.). Since scleractinian corals engage in a very similar symbiosis, these data could potentially be extrapolated to coral reefs as well.

Further studies are needed since high concentrations of TBT and other organotins in the marine environ- ment remain of concern, mainly because antifouling paints containing them are used on commercial and other large vessels, even though their use has been banned on smaller boats in many countries. Since TBT degradation can take decades in sediments, dumping of dredged material from harbours to less affected areas can lead to a larger span of polluted habitats in the future (Stewart \& de Mora 1990). Furthermore, numerous countries still lack regulation concerning the use of organotins.

Acknowledgements. We thank the anonymous referees who helped us improve the manuscript. This research was supported by a grant of the National Scientific and Engineering Research Council (NSERC) to É.P. A.M. was supported by NSERC and the Fonds pour la Formation de Chercheurs et l'Aide à la Recherche (FCAR).

\section{LITERATURE CITED}

Benson AA (1990) Arsenic depuration via the Tridacna gill membrane. Z Naturf 45c:793-796

Benson AA, Summons RE (1981) Arsenic accumulation in Great Barrier Reef invertebrates. Science 211:482-483

Blanquet RS, Emanuel D, Murphy TA (1988) Suppression of exogenous alanine uptake in isolated zooxanthellae by cnidarian host homogenate fraction: species and symbiosis specificity. J Exp Mar Biol Ecol 117:1-8

Brown B, Howard S (1985) Response of coelenterates to trace metals: a field and laboratory evaluation. Proc 5th Int Coral Reef Congr 6:465-470

Bryan GW, Gibbs PE, Hummerstone LG, Burt GR (1989) Uptake and transformation of ${ }^{14} \mathrm{C}$-labelled tributyltin chloride by the dog-whelk, Nucella lapillus: importance of absorption from the diet. Mar Environ Res 28:241-245

Clark KB, Jensen KR (1982) Effects of temperature on carbon fixation and carbon budget partitioning in the zooxanthellal symbiosis of Aiptasia pallida (Verrill). J Exp Mar Biol Ecol 64:215-230

Clayton W Jr (1986) Ingestion, digestion and assimilation efficiency of the sea-anemone Aiptasia pallida fed zooplankton prey. Int Revue Ges Hydrobiol 7:709-717

Clayton WS Jr, Lasker HR (1984) Host feeding regime and zooxanthellal photosynthesis in the anemone Aiptasia paliida (Verrill). Biol Bull 167:590-600

Cocchieri RA, Biondi A, Arnese A, Pannaccione A (1993) Total tin and organotin in seawater from the Gulf of Naples, Italy. Mar Pollut Bull 26:338-341

Cook CB, D'Elia CF, Muller-Parker G (1988) Host feedıng and nutrient sufficiency for zooxanthellae in the sea anemone Auptasia pallida. Mar Biol 98:253-262

Cook CB, Muller-Parker G, D'Elia CF (1992) Ammonum enhancement of dark carbon fixation and nitrogen limitation in symbiotic zooxanthellae: effects of feeding and starvation of the sea anemone Aiptasia pallida. Limnol Oceanogr 37:131-139

Day RJ (1994) A.lgal symbiosis in Bunodeopsis: sea anemones with 'auxiliary' structures. Biol Bull 186:182-194

Den Besten PJ, Herwig HJ, van Donselaar EG, Livingstone DR (1990) Cytochrome P-450 monooxygenase system and benzo(a)pyren metabolısm in echinoderms. Mar Biol 107. $171-177$

Espourteille FA, Greaves J, Hugget RJ (1993) Measurement 
of tributyltin contamination of sediment and Crassostrea virginica un the southern Chesapeake Bay. Environ Toxicol Chem 12:305-314

Evans DW, Laughlin RB (1984) Accumulation of bis(tributyltin) oxide by the mud crab Rhithropanopeus harrisit. Chemosphere 13:213-219

Firman J, Gassman N (1995) Enzyme induction, and partitioning, metabolism and depuration of chlordane in a scleractunian coral. 2nd SETAC World Congress (Abtracts). Soc Environ Toxicol Chem, SETAC Press, Pensacola, p 27

Fish RH, Kimmell EC, Casida JE (1976) Bioorganotin chemistry: reactions of tributyltin derivatives with cytochrome P-450 dependent monooxygenase enzyme system. J Organomet Chem 118:41-54

Fitt WK, Rees TAV, Braley RD, Lucas JS. Yellowlees D (1993) Nitrogen flux in giant clams: size-dependency and relationship to zooxanthellae density and clam biomass in the uptake of dissolved inorganic nitrogen. Mar Biol 117. $381-386$

Garrigue C, Clavier J, Boucher G (1992) The use of photosynthesis inhibitor (DCMU) for in situ metabolic and primary production studies on soft bottom benthos. Hydrobiologia 246:141-1.45

Gassman NJ, Kennedy CJ (1992) Cytochrome P-450 content and xenobiotic metabolizing enzyme activities in the scleractinian coral, Favia fragum (Esper). Bull Mar Sci 50: $320-330$

Glider WV, Phipps DW Jr, Pardy RL (1980) Localization of symbiotic dinoflagellate cells within tentacle tissue of Aiptasia pallida (Coelenterata, Anthozoa). Trans Am Microsc Soc 99:426-438

Grigg RW, Dollar SJ (1991) Natural and anthropogenic disturbance on coral reefs. In: Dubinsky $Z$ (ed) Ecosystems of the world no. 25: coral reefs. Elsevier Science Publishers, Amsterdam, p 439-452

Guolan H, Yong W (1995) Effects of tributyltin chloride on marine bivalve mussels. Water Res 29:1877-1884

Harland AD. Brown BE (1989) Metal tolerance in the scleractinıan coral Porites lutea. Mar Pollut Bull 20:353-357

Harland AD, Bryan GW, Brown BE (1990) Zinc and cadmium absorption in the symbiotic anemone Anemonia viridis and the non-symbiotic anemone Actinia equina. J Mar Biol Ass UK 70:789-802

Harland AD, Nganro NR (1990) Copper uptake by the sea anemone Anemonia viridis and the role of zooxanthellae in metal regulation. Mar Biol 104:297-301

Higashiyama T, Shiraishi H. Otsuki A, Hashimoto S (1991) Concentrations of organotin compounds in blue mussels from the wharves of Tokyo Bay. Mar Pollut Bull 22: $585-587$

Hinde R (1988) Symbiotic nutrition and nutrient limitation. Proc 6th Int Coral Reef Symp 1:199-204

Howard LS. Brown BE (1984) Heavy metals and reef corals. Oceanogr Mar Biol Ann Rev 22:195-210

Howard LS. Crosby DG. Alino P (1986) Evaluation of some methods for quantitatively assessing the toxicity of heavy metals to corals. In: Jokiel PL, Richmond RH, Rogers RA (eds) Coral reef population biology. Hawaii Institute of Mar Biol Tech Rep No. 37, p 452-464

Kaplan EH (1988) A field guide to southeastern and Caribbean seashores. Peterson Field Guides, Houghton Mifilin Company, Boston

Khan MAQ, Kamal A, Wolin RJ, Runnels J (1972) In vivo and in vitro epoxidation of aldrin by aquatic food chain organisms. Bull Environ Contam Toxicol 8:219-228

Lee RF (1985) Metabolism of tributyltin oxide by crabs, oysters and fish. Mar Environ Res 17:145-148
Lee RF (1991) Metabolism of tributyltin by marine animals and possible linkages to effects. Mar Environ Res 32:29-35

Lee RF, Valkirs AO, Seligman PF (1989) Importance of microalgae in the biodegradation of tributyltin in estuarine waters. Environ Sci \& Technol 23:1515-1518

Maguire RJ, Wong PTS, Rhamey JS (1984) Accumulation and metabolism of tri-n-butyltin cation by a green algae, Ankistrodesmus falcatus. Can J Fish Aquat Sci 41:537-540

McAuley PJ, Cook CB (1994) Effects of host feeding and dissolved ammonium on cell division and nitrogen status of zooxanthellae in the hydroid Myrionema amboinens. Mar Biol 121:343-348

Mercier A, Pelletier É. Hamel JF (1994) Metabolism and subtle toxic effects of butyltin compounds in starfish. Aquat Toxicol 28:259-273

Muller-Parker G (1987) Seasonal variation in light-shade adaptation of natural populations of the symbiotic sea anemone Aiptasia pulchella (Carlgren, 1943) in Hawaii. $J$ Exp Mar Biol Ecol 112:165-183

Muller-Parker G, Cook CB, D'Elia CF (1990) Feeding affects phosphate fluxes in the symbiotic sea anemone Aiptasia pallida. Mar Ecol Prog Ser 60:283-290

Muscatine L (1974) Endosymbiosis of cnidarian and algae. In: Muscatine L, Lenhoff HM (eds) Coelenterate blology: reviews and perspectives. Academic Press, New York, p 359-396

Muscatine L (1990) The role of symbiotıc algae in carbon and energy flux in reef corals. In: Dubinsky $Z$ (ed) Ecosystems of the world no. 25: coral reefs. Elsevier Science Publishers, Amsterdam. p 75-87

Peters EC, Meyers PA, Yevich PP, Blake NJ (1981) Bioaccumulation and histopathological effects of oil on a stony coral. Mar Pollut Bull 12:333-339

Powers MF, Beavis AD (1991) Triorganotins inhibit the mitochondrial inner membrane anion channel. J Biol Chem 266:17250-17256

Rice SD, Short JW, Stickle WB (1989) Uptake and catabolism of butyltin by blue crab fed TBT contaminated prey. Mar Environ Res 27:137-145

Saint-Louis R, Pelletier E, Marsot P, Fournier R (1994) Distribution and effects of tributyltin chloride and its degradation products on the growth of the marine alga Pavlova lutheri in continuous culture. Wat Res 28:2533-2544

Seligman PF, Valkirs AO, Stan PM, Lee RF (1988) Evidence of rapid degradation of tributyltin in a marina. Mar Pollut Bull 19:531-534

Shick JM (1991) A functional biology of sea anemones. Chapman \& Hall, London

Steen RG (1986) Evidence for heterotrophy by zooxanthellae in symbiosis with Aiptasia pulchella. Biol Bull 170:267-278

Steen RG. Muscatine L (1984) Daily budgets of synthetically fixed carbon in symbiotic zoanthids. Biol Bull 167:477-487

Stewart C, de Mora SJ (1990) A review of the degradation of tri(n-butyl)tın in the marine environment. Environ Technol 11:565-570

Stewart C, de Mora SJ (1992) Elevated tri(n-butyl)tin concentrations in shellfish and sediments from Suva Harbour, Fjji. Appl Organomet Chem 6:507-512

Stewart C. Thompson JAJ (1994) Extensive butyltin contamination in southwestern coastal British Columbia, Canada. Mar Pollut Bull 28:601-606

Trench RK (1981) Cellular and molecular interactions in symbiosis between dinoflagellates and marıne invertebrates. Pure Appl Chem 53:819-835

Uhler AD, Durell GS, Steunhauer WG, Spellacy AM (1993) Tributyltin levels in bivalve mollusks from the east and west coasts of the United States: results from the 
1988-1990 National Status and Trends Mussel Watch Project. Environ Toxicol Chem 12:139-153

Vandermeulen JH, Davis ND, Muscatine L (1972) The effect of inhibitors of photosynthesis on zooxanthellae in corals and other marine invertebrates. Mar Biol 16:185-191

Wilkerson FP, Muscatine L (1984) Uptake and assimilation of

This article was presented by S. W. Fowler (Senuor Editorial Advisorl, Monaco dissolved nitrogen by a symbiotic sea anemone. Proc $R$ Soc Lond Ser 221:71-86

Yellowlees D, Dionisio-Sese ML, Masuda K, Maruyama T, Abe T, Baillie B, Tsuzuki M, Miyachı S (1993) Role of carbonic anhydrase in the supply of inorganic carbon to the giant clamzooxanthellae symbiosis. Mar Biol 115:605-611

Manuscript first received: May 7, 1996

Revised version accepted: August 27, 1996 